УДК 373.5:37.01-053.6

DOI:

Олександр Шпак, доктор педагогічних наук, професор Національного педагогічного університету імені М.П. Драгоманова Світлана Булавенко, кандидат педагогічних наук, докторант Інституту проблем виховання НАПН Украӥни

Наталія Бендерець, кандидат педагогічних наук, доиент кафедри суспільно-гуманітарної освіти, в.о. ректора інституту, Комунальний навчальний заклад Київської обласної ради “Київський обласний інститут післядипломної освіти педагогічних кадрів"

\title{
ФОРМУВАННЯ СПОЖИВЧОЇ КУЛЬТУРИ ШКОЛЯРІВ ЯК ОСНОВИ СОЦАЛЬНОЇ АКТИВНОСТІ ОСОБИСТОСТІ
}

У статті висвітлено проблеми формування споживчої культури учнів закладів загальної середньої освіти, як основи розвитку сочіальної активності. Аналізуються критерії та показники сформованості споживчої культури учнів. Докладно описані методологічні функції прочесу формування споживчої культури школярів, як засобу соиіалізації. Автори знайомлять з рівневим підходом до формування спожсичої культури школярів, який включає в себе чотири рівні: методологічний, теоретичний, методичний, практичний.

Ключові слова: споживча культура; споживчі знання; учні закладів загальної середньої освіти; соиіалізація; методологія.

Jim. 5.

Oleksandr Shpak, Doctor of Sciences (Pedagogy), Professor of the National Mykhaylo Drahomanov Pedagogical University Svitlana Bulavenko, Ph D.(Pedagogy), Doctoral Student of the Institute of Education Problems of the National Academy of Sciences of Ukraine

Nataliya Benderets, Ph.D.(Pedagogy), Associate Professor of the Social and Humanitarian Education Department, Acting Rector of the Institute, Municipal Educational Institution of Kyiv Regional Council "Kyiv Regional Institute of Postgraduate Education of Pedagogical Staff"

\section{FORMING CONSUMER CULTURE OF SCHOOLCHILDREN AS A BASIS OF SOCIAL ACTIVITY OF PERSONALITY}

The article deals with the problems of formation of consumer culture of students of institutions of general secondary education, as the basis for the development of social activity. The criteria and indicators of the formation of the consumer culture of students are analyzed. The article presents the detailed description of the methodological functions of the formation of the consumer culture of schoolchildren, as a means of socialization. The authors introduce the level approach to the formation of the consumer culture of schoolchildren, which includes four levels: methodological, theoretical, methodological, and practical.

Consumer culture is a set of material and spiritual values, knowledge, patterns and norms of consumer behavior, socially significant and implemented in practical activities. Formation of socially meaningful values, knowledge, norms and patterns of behavior, a reasonable combination of the material and spiritual consumer, corresponding to the Ukrainian mentality, should become a purposeful and systematic pedagogical process.

The process of formation of consumer culture, in our opinion, is effective in the conditions of consumer education, oriented to the socialization of personality. The formation of a consumer culture can be judged on the basis of how and in what concrete form is implemented in practice a system of personal relationships to consumption, directing the person to the practical application of norms and evaluation criteria, which help to adequately organize the behavior and activities that determine the creative solution of emerging life and professional tasks and problems.

In the process of forming the consumer culture of schoolchildren, we distinguish the following didactic conditions: goal-setting, informational filling of spatio-temporal limits of perception by students of consumer behavior (content), individualization and differentiation of the educational process, the use of methods and forms of active learning, the use of modern multimedia technologies, the integrative nature of the study of economic disciplines and organization of practical activities.

The organizational-activity conditions include: realization of practical activity of schoolchildren, accessible age; organization of joint educational activities of the school, family and other social institutions, etc. In our

Н. Бендерець, 2019 
opinion, improvement of the process of teaching consumer knowledge can be carried out in the following directions: strengthening of state support for the process of learning the basics of consumer knowledge; the introduction of special courses on the culture of consumer behavior in schools; organization of work on the publication of textbooks, manuals and other literature on the problems of consumption; regular holding of competitions and competitions among pupils on mastering of consumer knowledge.

Keywords: consumer culture; consumer knowledge; pupils of institutions of general secondary education, socialization; methodology.

П остановка проблеми. Зміни сучасного соціуму, зумовлені ринковими механізмамигосподарювання, зростанням темпів економічного і науковотехнологічного розвитку, по-новому ставлять питання входження молоді в систему соціальних відносин, визначають соціальне замовлення на діяльність системи освіти, що забезпечує підготовку юних громадян до життя в суспільстві, формування особистості, здатної успішно діяти в рамках характерної для суспільства культури. Саме школа - основний соціальний інститут, за допомогою якого суспільство може здійснювати керовану соціалізацію молоді, готувати до вирішення стратегічних завдань соціальноекономічного розвитку. Сьогодні акценти в навчально-виховній роботі зміщуються на своєчасне забезпечення повноцінного функціонування особистості в середовищі, тобто іiі соціалізацію [2].

Сучасне суспільство, ринок праці, соціальні перетворення вимагають від системи освіти нових підходів і знань, що сприяють формуванню свідомого, підготовленого до нових викликів громадянина, здатного жити та діяти в сучасному світі, що швидко змінюється. Споживча освіта $є$ невід'ємною складовою, яка дозволяє формувати стале, демократичне та розвинуте громадянське суспільство й громадян, здатних його розвивати та успішно взаємодіяти. Але проблема формування окремих споживчих знань в учнів залишається ще недостатньо розробленою.

Аналіз останніх досліджень. Проблемою формування споживчої культури в підростаючого покоління займалися Г. Григоренко, О. Гриценчук, Н. Кривошея, Д. Лазаренко, О. Лихолат, Л. Савченко, Н. Слюсаренко, 3. Філончук й ін. Проте результатів комплексного вивчення та впровадження споживчої культури в освітній процес на сьогодні недостатньо.

Метою статті $\epsilon$ висвітлити проблеми формування споживчої культури учнів закладів загальної середньої освіти, як основи розвитку соціальної активності.

Виклад основного матеріалу. Шкільна освіта як значущий механізм культури є провідним джерелом формування у підростаючого покоління рівня соціальної зрілості, достатнього для забезпечення автономності особистості, ï самостійності у вирішенні особистісно значущих проблем в різних сферах життєдіяльності, а також сприяє розвитку базової культури особистості, важливою складовою якою є споживча культура [3].

Споживча культура - це сукупність матеріальних і духовних цінностей, знань, зразків і норм поведінки споживачів, соціально значущих і реалізованих в практичній діяльності. Споживча культура відіграє велику роль в загальній культурі особистості і впливає на розвиток всіх ¥ї компонентів (знання, якості, ціннісні орієнтації тощо), через споживчу поведінку [4].

Проблема поведінки споживачів і розвитку споживчої культури багатогранна. Ця проблема набуває особливої актуальності в умовах глобального поширення масової культури, ключовими цінностями якої виступають розвага, гедонізм і споживання. Разом з тим, тенденції культурного розвитку сучасності несуть в собі такі позитивні зміни, як створення сприятливих умов для розширеного діалогу культур, формування толерантності, зростання інформаційних та освітніх ресурсів, розширення сфери послуг i товарів. Підростаюче покоління дуже чутливо реагує на навколишнє суспільство - його цінності, політичні та економічні суперечності, не завжди адекватно пропускаючи їх через призму формування свідомості та самосвідомості.

Таким чином, виникла необхідність в споживчій освіті підростаючого покоління, починаючи зі шкільної лави. Під споживчою освітою ми розуміємо процес і результат засвоєння учнями знань, вироблення умінь i навичок, виховання почуттів, необхідних для здійснення розумної споживчої поведінки.

Щодня кожен з нас хоча б на п'ять хвилин стає звичайним споживачем - покупцем товарів, користувачем послуг. Як показує практика, дуже часто нам не вистачає знань, щоб знайти вихід в тій чи іншій ситуації, захистити і відстояти свої законні права.

Вивчення основ споживчих знань дозволяє сформувати у школярів такі важливі і для особистості, і для суспільства в цілому якості, як відповідальність, ощадливість, передбачливість, цілеспрямованість, свідомість. Важливо, щоб 


\section{ФОРМУВАННЯ СПОЖИВЧОЇ КУЛЬТУРИ ШКОЛЯРІВ ЯК ОСНОВИ}

СОЦАЛЬНОЇ АКТИВНОСТІ ОСОБИСТОСТІ

молоді люди навчилися самостійно отримувати інформацію при купівлі або отриманні послуги, застосовувати на практиці знання з відстоювання своїх споживчих прав, знаходити шляхи вирішення конфліктів, користуватися основними механізмами захисту прав споживачів.

Очевидно, що споживча освіта підвищує безпеку життя. Грамотний покупець звертає увагу не тільки на вартість товару, а й на термін його виготовлення, чистоту і якість, він заздалегідь дізнається про реноме фірми, послугами якої збирається скористатися [5].

Формування в учнів соціально значущих цінностей, знань, норм і зразків поведінки, розумного поєднання в споживача матеріального i духовного, що відповідає українському менталітету, має стати цілеспрямованим і систематичним педагогічним процесом.

Споживча освіту передбачає не просто оволодіння учнями знаннями, вміннями i навичками, а розробку дидактичної системи, спрямованої на досягнення спільної мети діяльності школи як соціального інституту в їі взаємодії з соціальним оточенням [4].

Процес формування споживчої культури, на наш погляд, ефективний в умовах споживчої освіти, орієнтованої на соціалізацію особистості. Соціалізацію ми розуміємо як процес і результат засвоєння знань, умінь, формування якостей особистості, системи ціннісних уявлень про взаємозв'язки явищ економічного та соціального життя, досвіду та морально-ціннісної мотивації діяльності, що дозволяють особистості самовизначитися і самореалізуватися в діяльності, адаптуватися та інтегруватися в існуючі та прогнозовані соціально-економічні умови 3 урахуванням морально-етичних установок суспільства [5].

Організація споживчої освіти в школі має свої особливості: по-перше, учні - в силу психовікових характеристик, сприйнятливі до отримання нових знань у групі, в тому числі і необхідних для споживача; по-друге, школярі, особливо підліткового, старшого шкільного віку, прагнуть до вступу в самостійне життя, що пояснює практичний інтерес до споживчої освіти, до вироблення навичок і умінь орієнтування на ринку; по-третє, проводиться активна робота по підготовці та перепідготовці вчителів, здатних вирішити це нове для України завдання [4].

У процесі формування споживчої культури учні покликані вивчати не об'єкт, а перш за все себе самих, повинні освоювати свій світ, формувати свою життєву позицію. Крім цього, психологічним фундаментом особистості майбутнього професіонала в будь-якій галузі людської діяльності, в тому числі і економічної, виступають такі базові характеристики, як особистісна спрямованість і компетентність [3].

У зв'язку з цим на перший план виступає особистісний критерій. Він включає в себе наступні показники: спрямованість особистості (соціально значущі важливі для життя орієнтації; розвинена соціальна мотивація, система особистісно і соціально важливих духовних потреб); інтелектуальні вміння та здібності (критичність, самостійність, аналітичність мислення) і емоційно-вольові та морально-етичні якості особистості (самостійність, організованість, самоконтроль).

У процесі формування основ споживчої культури в учнів розвивається потреба в самозміні, зацікавленості в знанняхтрансформаціях, психологічних знаннях, знанняхінструментах, які дозволяють знайти і побудувати свою діяльність. Тому другим значущим критерієм ми виділяємо когнітивний.

Для когнітивного критерію характерні наступні показники: економічна грамотність, обсяг і системність споживчих знань, правова грамотність у сфері поведінки споживачів.

Найбільш ефективною в споживчій поведінці є стадія апробації, коли в учня з'являється можливість закріпити освоєні на заняттях нові способи поведінки у своїй навчальній i позанавчальній діяльності. Отже, наступний за важливістю виділений нами критерій операційний, в якому в тісному взаємозв'язку перебувають два рівнозначних для особистості показника: сформованість морально-етичної моделі споживчої поведінки і реалізація засад здорового і осмисленого способу життя, так як моральний, морально-етичний компонент сприяе не тільки формуванню моральної та інтелектуально розвиненої особистості, але й правильній постановці й успішному вирішенню економічних і соціальних проблем в суспільстві [5].

Таким чином, про сформованість споживчої культури можна судити на підставі того, як і в якій конкретній формі реалізується на практиці система особистісних відносин до споживання, що направляють особистість на практичне застосування норм і критеріїв оцінки, які допомагають адекватно організувати поведінку і діяльність, що визначають творче вирішення виникаючих життєвих і професійних завдань і проблем.

Зміст навчального матеріалу 3 основ споживчої культури розкривається через 


\section{ФОРМУВАННЯ СПОЖИВЧОЇ КУЛЬТУРИ ШКОЛЯРІВ ЯК ОСНОВИ СОЦІЛЬНОЇ АКТИВНОСТІ ОСОБИСТОСТІ}

педагогічні технології, пріоритетними серед яких визначено особистісно-орієнтовані, що дозволяють на практиці реалізувати основні принципи педагогіки співробітництва. Реалізація технологій розвиваючого навчання дозволить сформувати у школярів цілісний образ практичної діяльності, вплине на розвиток пізнавальної, рефлексивної, прогностичної функцій економічного мислення. Технології проблемного навчання забезпечують розвиток пізнавальної та регулятивної функцій аналітичного мислення і впливають на становлення самосвідомості учнів [4].

Для будь-якого процесу характерний ряд умов, в яких він протікає. У процесі формування споживчої культури школярів ми виділяємо наступні дидактичні умови: цілепокладання, інформаційна наповненість просторово-часових меж сприйняття учнями споживчої поведінки (утримання), індивідуалізація і диференціація навчального процесу, використання методів і форм активного навчання, застосування сучасних мультимедійних технологій, інтегративний характер вивчення економічних дисциплін та організація практичної діяльності.

Особистість розвивається і формується в діяльності. До організаційно-діяльнісних умов відносяться: реалізація практичної діяльності школярів, доступної віку; організація спільної виховної діяльності школи, сім’ї та інших соціальних інститутів тощо [1].

Вирішуючи питання теорії проектування процесу формування споживчої культури школярів, як засобу їх соціалізації, ми виділяємо наступні методологічні функції.

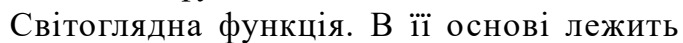
уявлення особистості про навколишній світ, про специфічну форму пізнання людини і місце людини в цьому світі. Ця функція визначає ціннісні орієнтації учнів. Світоглядна функція передбачає необхідність оволодіння учнями соціальноекономічними, культурологічними, споживчими знаннями, посилення ролі самосвідомості учнів.

Соціальна функція обгрунтовує необхідність цілісного аналізу не тільки об'єктивних соціальноекономічних відносин і потреб, які диктують основні напрямки діяльності, але і суб'єктивних мотивів, інтересів, ціннісних орієнтацій особистості.

Культурологічна функція $є$ істотним чинником формування і розвитку споживчої культури школярів. Культура покликана забезпечити гуманізацію, духовний розвиток суспільства, вирішити його кардинальні морально-естетичні проблеми і тим самим впливати на сферу праці, пізнання, побуту і дозвілля. Культурологічна функція проявляється через соціокультурну активність людини, яка виступає не тільки в якості особистої цінності, а й як основа ефективності педагогічної діяльності.

Інтеграційна функція поєднує в собі соціальноекономічні, науково-технічні, психологопедагогічні, культурологічні, професійнопедагогічні, особистісно-діяльнісні компоненти. Тому цілісне формування споживчої культури неможливо без здійснення інтеграційних процесів.

Прогностична функція забезпечує передбачення соціально-економічних умов, в яких буде розвиватися споживча освіта, нові вимоги до випускника загальноосвітньої школи, до рівня соціалізації особистості.

Рівневий підхід до формування споживчої культури школярів включає в себе чотири рівні: методологічний, теоретичний, методичний, практичний (праксеологічний).

1) Методологічний рівень пов'язаний 3 філософською та економічною підготовкою школярів. Він передбачає залучення учнів до філософських знань, дослідження пізнавального, соціального, ціннісного ставлення учнів до навколишньої дійсності. Його реалізація пов'язана 3 наявністю таких інтеграційних (зовнішніх i внутрішніх) умов, як:

- облік культурологічного підходу до допрофільної та профільної підготовки учнів;

- осмислення сутності теорії споживчої культури; [2].

- аксіологічний підхід до споживацької культури

2) Теоретичний рівень пов'язаний 3 економічною підготовкою учнів. Він включає оволодіння школярами системою економічних, споживчих та цивільно-правових знань - основи для здійснення успішної навчально-пізнавальної та професійної діяльності. Він реалізовувався за наявності таких інтеграційних умов:

- моделюванні умов і процесу управління формуванням споживчої культури;

- особистісно-орієнтованого підходу до учнів;

- діяльнісного підходу до формування споживчої культури школярів [2].

3) Методичний рівень формування споживчої культури ми пов'язали з розробкою технологічних підходів до вирішення проблеми. Цей рівень включає спільну продуктивну діяльність вчителя і учнів в процесі формування споживчої культури через вивчення предметного матеріалу, організацію споживчого середовища, формування стійкої потреби в пізнанні. Здійснюється за наявності таких інтеграційних умов: 


\section{ФОРМУВАННЯ СПОЖИВЧОЇ КУЛЬТУРИ ШКОЛЯРІВ ЯК ОСНОВИ СОЦІАЛЬНОЇ АКТИВНОСТІ ОСОБИСТОСТІ}

\begin{abstract}
- проблемно-варіативної побудови занять;
- орієнтація учнів в цінностях споживчої культури;

- структурування та субординація споживчих знань [2].

4) Практичний рівень формування споживчої культури школярів був пов'язаний 3 переходом навчання в самонавчання, пізнання в самопізнання, управління в самоврядування, контролю в самоконтроль. Характеризується сформованістю умінь і навичок грамотної поведінки споживача, спілкування з однолітками і вчителями, адекватної самооцінки, умінь самостійно ставити мету, прогнозувати результати своєї діяльності, критично оцінювати досягнуті результати. Даний рівень реалізовувався за наявності таких інтеграційних умов:

- отримання та використання в практичній діяльності споживчих знань і умінь;

- субординація цінностей споживчої культури;

- організація занять на основі проблемноваріативного підходу до педагогічного процесу [2].
\end{abstract}

Процес формування споживчої культури школярів передбачає постановку, обгрунтування, формування, розгортання цілей навчання вчителем i прийняття або самостійну постановку цілей поведінки споживача з боку учня.

Висновки. Отже, удосконалення процесу викладання споживчих знань може здійснюватися, на нашу думку, в рамках наступних напрямків: посилення державної підтримки процесу навчання основам споживчих знань; введення спеціальних курсів 3 культури споживчої поведінки в школах; організація роботи 3 видання підручників, посібників та іншої літератури з проблем споживання; регулярне проведення конкурсів та олімпіад серед школярів з оволодіння споживчими знаннями.

\section{ЛІТЕРАТУРА}

1. Бим-Бад, Б. М. Мир постепенно окружает нашу школу. URL: http://www.bim-bad.ru/biblioteka/ article full.php?aid=1155\&binn rubrik pl articles=164.

2. Булавенко С.Д., Бабяк М.M., Терес В.I., Шпак О.Т. Економіка для життя : навчальнометодичний посібник. Дрогобич : Редакційновидавничий відділ Дрогобицького державного педагогічного університету імені Івана Франка, $2018.432 \mathrm{c}$.
3. Канішевська Л. В. Виховання соціальної зрілості старшокласників загальноосвітніх шкілінтернатів у позаурочній діяльності : монографія. Київ, 2011.368 с.

4. Лихолат О. (2011). “Основи споживчих знань” в циклі підготовки вчителя технології, спеціалізація “Основи домашнього господарювання”. Науковий часопис НПУ імені М. П. Драгоманова. Серія 5. Педагогічні науки: реалії та перспективи, 30, С. 120-125.

5. Пометун О.І., Пилипчатіна Л. М., Сущенко I. М. Уроки для сталого розвитку : посібник для вчителя 3 навчального курсу за вибором для учнів 8-го класу загальноосвітніх шкіл. Дніпро, 2013.

\section{REFERENCES}

1. Bim-Bad, B. M. Mir postepenno okruzhaet nashu shkolu [The world is gradually surrounding our school]. Available at: http://www.bim-bad.ru/ biblioteka/article_full.php? aid=1155 \&binn rubrik_pl_articles=164.[in Russian].

2. Bulavenko, S.D., Babiak, M.M., Teres, V.I. \& Shpak, O.T. (2018). Ekonomika dlia zhyttia : navchalno-metodychnyi posibnyk [Economics for Life: A manual. Drohobych: Editorial and Publishing Department of Drohobych Ivan Franko State Pedagogical University,432 p.[in Ukrainian].

3. Kanishevska, L. V. (2011). Vykhovannia sotsialnoi zrilosti starshoklasnykiv zahalnoosvitnikh shkil-internativ u pozaurochnii diialnosti : monohrafiia [Education of social maturity of high school students of boarding schools in extra-curricular activities: monograph]. Kyiv, 368 p.[in Ukrainian].

4. Lykholat, O. (2011). “Osnovy spozhyvchykh znan" v tsykli pidhotovky vchytelia tekhnolohii, spetsializatsiia "Osnovy domashnoho hospodariuvannia" [Consumer Knowledge Basics in Technology Teacher Training Cycle, Specialization in Household Fundamentals]. Scientific journal of MP Drahomanov NPU. Series 5. Pedagogical sciences: realities and perspectives, 30, pp. 120 125. [in Ukrainian].

5. Pometun, O.I., Pylypchatina, L. M. \& Sushchenko, I. M. (2013). Uroky dlia staloho rozvytku [Lessons for sustainable development]. A teacher's guide for an elective course of choice for 8th grade students in general schools. Dnipro. [in Ukrainian].

Стаття надійшла до редакції 21.06.2019

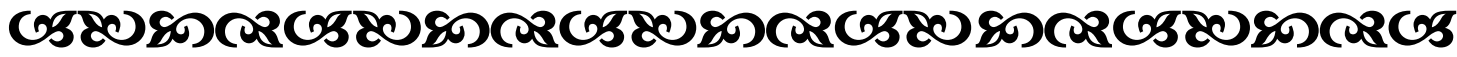

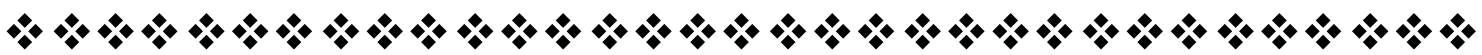

